\title{
Examining the Relationship between Corporate Social Responsibility and Financial Performance of Manufacturing Companies in Tigray Regional State, Ethiopia
}

\author{
Yitbarek Abrha Asfaw ${ }^{1}$, Araya Hagos Gebreegziabher ${ }^{2}$ and \\ Hiwot Kebede Aregawi ${ }^{3}$
}

\begin{abstract}
Recently the concept of corporate social responsibility (CSR) is being discussed globally. Previous studies investigated the relationship between CSR and corporate financial performance (CFP) and findings show varied results. In this study, we explore and test the relationship between financial performance and social responsibility activities undertaken by private manufacturing firms in Tigray Regional State, Ethiopia. We used survey instruments to collect data from 34 firms over a period of three years. Then, using empirical methods we tested the hypothesis of the direction of the relationship between CSR and CFP. Findings indicate that CSR is positively related to better financial performance, as represented by ROA, ROE, and ROS. This relationship is statistically significant at the $p<0.01$ level of significance, supporting the view that socially responsible firm performance can be attached with achieving higher financial benefits. Hence, firms should recognize and instill CSR initiatives into their corporate culture and business operations because increases in CSR investments can lead to higher CFP while balancing the needs of their internal and external stakeholders.
\end{abstract}

Keywords: Corporate Social Responsibility, Financial Performance, ROA, ROE, and ROS.

http://dx.doi.org/10.4314/ejbe.v5i2.3

\footnotetext{
${ }^{1}$ Corresponding Author, College of Business and Economics, Mekelle University E-mail: yitbarek98@yahoo.com or yitbareka@mu.edu.et; Cell phone: +251-914-708139

${ }^{2}$ Assistant Professor, College of Business and Economics, Mekelle University E-mail: nahomaraya@yahoo.com; Cell phone: +251-914-725657

${ }^{3}$ Assistant Professor, College of Business and Economics, Mekelle University

E-mail: nanoethiopia@yahoo.com; Cell phone: +251-914-381657
} 


\section{Background and Problem Statement}

In today's rapidly changing business environment, firms of all sizes are under pressure to demonstrate ethical behavior. Business firms are accountable not just to owners or shareholders, but also to stakeholders, such as employees, consumers, suppliers, local communities, competitors, and the environment (Boddy, 2008). According to the social contracts theory, businesses must not just act in a responsible manner because it is in their commercial interest, but because it is how society expects the businesses to behave (Gray, Dillard, \& Spence, 1996).

Corporate social responsibility (CSR for short and also called corporate social performance, citizenship or sustainable responsible business) concept emphasizes community participation by business enterprises. It proposes that a private firm has responsibilities to society that extend beyond making a profit. It is the obligation of the firm's decision makers to make decisions and act in ways that recognize the relationship between the business and society. It is therefore important for a business to continue in its commitment to behave ethically and contribute to economic development while improving the quality of life of the work force and the surrounding community. This can be achieved through the various CSR activities that the business chooses to engage in for the benefit of its several stakeholders (McWilliams \& Siegel, 2001; Hill, 2006; Mwangi \& Jerotich, 2013).

It is generally accepted that corporate social responsibility/performance (CSR/CSP) could increase corporate financial performance (CFP). Socially responsible management understands that their company would receive respect in the business which can result in higher sales, enhance employee loyalty and attract better personnel to the company. In addition, CSR activities would focus on sustainability issues and may lower costs and improve efficiencies as well. The companies would be motivated to profit from a sustainable business (Cochran \& Wodd, 1984; Waddock \& Graves, 1997; and Boddy, 2008).

The study of CSR and its relation to financial performance is growing. Literature provides conflicting results on the relationship between CSR practice and firm financial performance with some studies showing a positive relationship (Waddock \& Graves, 1997; Hill, Ainscough, Shank, \& Manullang, 2007), others negative (Cordeiro \& Sarkis, 1997; Wagner, Van, Azomahou, \& Wehrmeyer, 2002) and still others showing that there is no relationship between the two variables (McWilliams \& Siegel, 2000; Aragón \& López, 2007). 
CSR is a recent phenomenon in Ethiopian business context. The concept of CSR is discussed mainly at the university and government levels and its implementation has been low (Potluri \& Temesgen, 2008; Robertson, 2009; Bedada \& Eshetu, 2011). However, these days good starts are evident in some industries. For instance, Tilahun (2011) mentions that social enterprises as well as multinational and local companies in the country are playing significant roles in environment perspective of CSR. By engaging in CSR activities the firms are working towards improving sustainable environmental management in the country.

Besides, Ghrmay (2013) investigated the status of CSR in Ethiopian business context using Carroll's model: economic, legal, ethical and philanthropic responsibilities. The study concludes that in Ethiopia the practice of CSR like many other African countries is on the economic aspect of the Carroll's model. Besides, the philanthropic responsibility aspect is widely practiced in the business. However, the legal and ethical responsibilities are the least in terms of practice.

Generally, the concept of CSR is not well developed in Ethiopia and the case is no different in Tigray Regional State. It is with this background that the study seeks to establish the relationship between corporate social responsibility practices and financial performance of firms operating in the region. We selected Tigray region as our study area for various reasons. To the researchers' best knowledge there is little study conducted on CSR in Tigray. This sparked an interest to narrow the research gap by providing empirical evidence regarding the concept and scope of CSR in the region. The geographical proximity of the sampled zones to our place of work and our familiarity with the local language and culture are additional factors. In this study we would like to investigate to what extent private manufacturing firms in the region are ethical and socially responsible. Also, we intend to examine the impact of CSR programs on CFP in sample firms.

The findings of this study can be used as inputs for management of the firms to evaluate the outcome of investment in CSR in terms of broad company focused goals and social benefits. This will motivate the firms to plan not only short-term profits but long-term sustainability of their business. The study also benefits varied needs of the stakeholders. Specifically, it benefits policy makers of the region to understand the concept and scope of corporate social responsibility and get an insight in CSR practices in the light of the manufacturing sector. This helps the policymakers establish code of conduct 
and policies that enhance CSR practices and solve problems that deter CSR implementation in the region. Employees and the society also benefit from the study. The study advises firms to improve the quality of life of the workforce through honoring labor rights, securing workplace safety and investing in the employees with internal and external training that help them do a better job. Similarly, it encourages firms to incorporate community welfare plans with their operations. Consequently, this lets the society benefit from CSR actions that target community development. Moreover, the study motivates firms to conduct business ethically and maintain high quality standards at reasonable prices. This helps customers and suppliers build healthy relationship with the firms seeking mutual benefit for both. Besides, this study can add to the existing body of literature on the relationship between CSR and CFP, in Ethiopian context.

The remainder of this article proceeds as follows. Section two reviews previous literature related to CSR and the association between CSR and CFP. Section three discusses the research design and methodology employed in this study. In section four empirical results are presented and discussed. Finally, section five draws conclusions based on the findings and it identifies policy options that target improvement of CSR programs by firms.

\section{Literature Review}

Literature about corporate social responsibility and its relationship with financial performance has been reviewed in this section.

\section{What is corporate social responsibility (CSR)?}

The concept of corporate social responsibility is being discussed globally. CSR is a concept about integrating the environmental and social interests into the business strategy and everyday practice of an organization. Sapkauskiene and Leitoniene define CSR as (2014, p.237):

"[...] activity policy and practice of organizations (and individuals) when the companies voluntarily integrate social and environmental matters into their business and combine them harmoniously with economic interests, and the relationships with all stakeholders are based on the valuable principles of respect for the individual, society and the environment."

It is therefore important for a business to continue in its commitment to behave ethically and contribute to economic development while improving the quality of life of the work force and the surrounding community. This can be achieved 
through the various CSR activities that the business chooses to engage in for the benefit of its various stakeholders (McWilliams \& Siegel, 2001; Hill, 2006; Mwangi \& Jerotich, 2013).

Companies perceived to have a strong CSR commitment would receive respect in the business which can result in higher sales. Besides, the firms often have an increased ability to attract and to retain employees, which leads to reduced turnover, recruitment, and training costs (Turban \& Greening, 1997). However, adopting the CSR concepts involves short term or long-term expenditures. The costs might involve the purchase of new environmentally friendly equipment, the change of management structures, or the implementation of stricter quality controls (Zapciu \& Hurduzeu, 2015). These practices are costly, but the increased productivity of the workers and improved quality of the products can generate positive cash flows that cover the associated costs. Thus, firms may actually benefit from socially responsible actions in terms of employee morale and productivity (Moskowitz, 1972).

\section{Measures of financial performance}

CFP can be measured by three possible alternative approaches: 1) marketbased measure (Cochran \& Wodd, 1984; Simerly, 2003); 2) accounting-based measure (Turban \& Greening, 1997); and 3) perceptual measure (Orlitzky, Schmidt, \& Rynes, 2003). The study of Griffin and Mahon (1997) provides a list with all measures of CFP used in their examined studies. The results of their literature review concluded that they have reviewed 51 studies on CSRfirm performance relationship and found that different types of FP measures have been used. Firm size, ROA, ROE, asset age, and ROS are the frequently used FP measures (Mishra \& Suar, 2010 p.574). Besides, Yang, Lin, and Chang (2010) measured financial performance using ROA, ROE and ROS.

\section{Measures of corporate social responsibility}

CSR concepts are composed of both internal factors (governance, employees, etc) and external factors (environmental and community impact). So, when determining CSR score one has to consider a wide variety of CSR components to address the problem in measuring CSR. Because social responsibility is qualitative in nature, there is the difficulty of defining a uniform social performance measure (Piatti, 2014). Hence, previous researches evaluated the relation between CSR and CFP using multiple measures.

Different scholars and researchers try to measure CSR using different indicators or dimensions. For instance, Clarkson (1995) offers a list of 
indicators evaluating CSP/CSR starting from the stakeholder framework. Others have used various CSR measures, such as self-constructed surveys (Aupperle, 1991), content analysis of documents (Wolfe, 1991), The Fortune reputation survey (Brown \& Perry, 1994), and the Dow Jones Sustainability Index (Lopez, Garcia, \& Rodriguez, 2007).

Some estimates of CSP try to measure numerical variables corresponding to the expression of some kind of impact or social output. The Kinder, Lyndenberger, Domini \& Co (KLD) ratings consider, for example, a corporation's social actions along the dimensions of local community, corporate governance, diversity, employee relations, environment, human rights and product (Andersen \& Olsen, 2011).

Giannarakis, Litinas, and Theotokas (2009) mentioned that the stakeholders that should be taken into account by CSR indicators include Suppliers, Corporate Governance, Environment, Employees, Customers, and Community. Igalens and Gond (2005) considered five main dimensions in measuring CSP. They cover the principal stakeholders: Community and Civil Society; Corporate Governance; Clients and Suppliers; Hygiene, Safety and the Environment; and Human Resources.

\section{The relation between CSR and CFP}

The topic of CSR has been widely studied among various researchers, and much of the focus has been on the role of corporation in a society as wealth maximization or providing socially responsible and ethical output to the society. Much of the literature in social responsibility has focused on the relationship between firms' social and financial performance.

There are mixed evidences of the link between CSR and CFP (Cochran \& Wodd, 1984; Ullmann, 1985). Aupperle, Carroll, and Hatfield (1985) and Wright and Ferris (1997) found a negative relationship between CSR and CFP. Posnikoff (1997), Waddock and Graves (1997), McWilliams and Seigel (2000), and Orlitzky et al. (2003) discovered a positive relationship between CSR and CFP, whereas in some studies there was no significant relationship found between the two variables (Welch \& Wazzan, 1999; and McWilliams \& Siegel, 2001).

\section{Theoretical framework and Hypothesis development}

There is no unified theory on the relationship between corporate social responsibility and financial performance (for instance, see Simpson \& Kohers, 2002; Margolis \& Walsh, 2003; Karagiorgos, 2010; Mwangi \& Jerotich, 2013). 
Several authors offer conceptual explanations for a negative, neutral, and positive relationship between CSR/CSP and FP. A negative relationship is supported by the neoclassical economists arguing that positive social performance causes the firm to incur costs that reduce profits and shareholder wealth (Waddock \& Graves, 1997; Preston \& O'Bannon, 1997). According to this line of reasoning, companies that engage in CSR programs are at a disadvantage because they are incurring unnecessary and avoidable costs. On the other hand, Preston and O'Bannon (1997) offer a "managerial opportunism hypothesis" as a rationale for a negative CSP-FP link. They suggest that when financial performance is strong, managers will reduce expenditures on social performance because they can increase short-term profitability and increase their personal compensation that is tied to short-term profitability. However, when financial performance is poor, managers will attempt to divert attention by incurring expenditures on conspicuous social programs.

The neutral relationship between CSR and FP is explained by the notion that the overall situation of the firm and society is so complex that a simple, direct relationship between CSP and FP does not exist (Waddock \& Graves, 1997). According to Ullman (1985), how no relationship exists between CSP and CFP is that there are so many intervening variables between CSP and FP that there is no reason to expect any relationship at all. Also, McWilliams and Siegel (2001) argue for a neutral, or nonexistent, relationship between CSP and FP from a framework based on a supply and demand theory of the firm which assumes shareholder wealth maximization. They argue that firms produce at a profit-maximizing level, including the production of social performance. This leads each firm to supply different amounts of social performance based on the unique demand for CSP the firm experiences. In equilibrium, the amount of CSP produced by firms will be different but profitability will be maximized and equal.

Quite a lot of explanations for a positive CSP-FP link also exist. First, a positive relationship exists because according to the "stakeholder theory", managers reap financial benefits by meeting the needs of stakeholders (Preston \& O'Bannon, 1997). A second viewpoint suggests that the actual costs of CSP are minimal compared to the potential benefits to the firm (Waddock \& Graves, 1997). For example, the cost of providing employee benefits may be much less than the productivity gains that result. A third argument for this positive association is the presence of tension between the explicit costs of a company (such as payment of debentures) and their implicit costs (such as environmental costs). As a result, according to Cornell and Shapiro (1987), 
companies that seek to reduce their implicit costs by means of socially irresponsible actions will incur greater explicit costs, resulting in a competitive disadvantage. Finally, Waddock and Graves (1997) suggest that there may be a positive CSP-FP link because of a simultaneous relationship combining slack resources and good management which results in a "virtuous circle" between CSP and FP.

When no single accepted theoretical foundation with clear empirical predictions exists, hypothesis development requires some judgment (Simpson \& Kohers, 2002). In this study, we predicted a positive relationship between CSR and CFP as the findings of most previous empirical studies reveal. Hence, the hypothesis of this current study could be formulated as follows:

$\boldsymbol{H}_{\boldsymbol{I}}$ : There is a positive relationship between CSR score and CFP.

\section{Research Methodology}

This section describes the methodology used in this research.

\section{Research Design}

The study employs a descriptive research design and establishes the relationship that exists between CSR and CFP in manufacturing firms. Applying descriptive design helps to explain phenomena as they exist and helps understand behavior and the meaning of that behavior in its particular context (Bryman, 2008).

\section{Population and Sample}

The population for this study is the entire privately owned manufacturing firms operating within Tigray Regional State, Ethiopia. Data collected from the regional Bureau of Industry and Trade showed that in the year 2014 there were 87 firms in the region engaged in manufacturing sector. We assumed that at least 30 firms can represent the target population and we actually managed to collect data from 34 firms. Hence, this study covers a total of 34 private firms, which have been in operation for at least three years. The population consisted of firms of varied year of operation- few months through two decades. Researches show that older firms have better experience of CSR and invest more in CSR programs than younger firms (Withisuphakorn \& Jiraporn, 2015). So, we believe the study sample should comprise relatively older firms. To include more mature firms in the study, we subjectively set the cut-off point at three years of operation. The sample firms were drawn from Mekelle City and other towns located at Western (Shire Endaselassie), Central (Axum and Adwa), Eastern (Adigrat and Wukro), and Southern (Alamata) zonal 
administrations. Hence, the sample was selected purposively to be consistent with the inclusion criteria.

\section{Data type, Source, and Collection method}

The study used both qualitative and quantitative data from primary and secondary sources of data. We employed structured questionnaire to gather qualitative data from the sample firms. Hence, the sources we used to assign the binary codes were CSR questionnaires gathered from appropriate offices of the firms. The questionnaire included four dimensions that are capable of clearly assessing a respondent's social responsibility orientation (see Table I). Financial data was obtained from audited reports of the companies covering the period of 2012-2014. We tried to replicate our data with the methodology used by most of similar previous studies to ensure they have important relationship with each other.

\section{Measuring CFP}

Financial performance of a firm can be measured different ways. Some studies used accounting measures while others used market-based measures (Waddock \& Graves, 1997; Simpson \& Kohres, 2002). This study used the accountingbased measure. In particular, we followed Waddock and Graves (1997), Mahoney and Roberts (2007), and Yang et al. (2010) in the use of traditional financial performance indicators including ROA, ROE and ROS.

To parallel the majority of studies, this study focused on accounting-based measures of CFP that are least likely to be manipulated (Yoshikawa \& Phan, 2003). Also, we preferred analyzing CFP based on accounting measures because the variables are not subject to the possibility of distortions due to inflation (Demsetz \& Villalonga, 2001). Thus financial performance was indicated by three financial variables: return on assets (ROA), return on equity (ROE) and return on sales (ROS). We measured return on assets as the net profit to total assets ratio. Similarly, return on equity was measured as net profit divided by equity and return on sales as net profit divided by total sales.

\section{Measuring CSR}

There are various ways we obtain CSR related data from firms. Aupperle et al. (1985) gathered CSP data through the surveying of 241 CEOs. Soana (2009) pointed out that social performance is measured in various studies by different methods, including surveys carried out using questionnaires. Waddock and Graves (1997) state that the MSCI ESG Index, one of the earliest tools for evaluating CSR performance and one of the most widely used and accepted 
CSP measurement, used CSR questionnaires from corporations' investor relations office to collect data on social performance of companies. Following those studies we employed survey questionnaire to collect CSR related data and measure them using binary system.

CSR concepts are composed of both internal (governance, employees, etc) and external (environmental, community impact, etc) factors. Researchers have used various proxy measures (indicators) to assess CSR initiatives. Mahoney and Roberts (2007) calculated a composite measure of CSR, based on community relations, diversity, employee relations, environment, international, product safety, and other ratings. Aupperle et al. (1985) used four components of CSR programs in their study -economic, legal, ethical, and philanthropic responsibilities. Brammer et al. (2006) and Fiori et al. (2009) adopted three parameters of CSR-employment, environment, and community. Karagiorgos (2010) measured CSR using two dimensions- social performance indicators and environmental performance indicators. Hence, we observe that CSR parameters are not the same for all studies- they differ according to particular study contexts and justifications of the researchers. In our study we employed four of five indexes - (1) customers and suppliers, (2) staff, (3) local community, and (4) natural environment- used by Igalens and Gond (2005). We have made the modification because our sample companies are those organized as Private Limited Company or Sole Proprietorship where corporate governance related issues such as remunerations to BOD members (a case in Share Companies) do not exist. Also, in this study the social performance indicators identified by Igalens and Gond (2005) have been modified in some way to represent the most common Social Responsibility Disclosures mentioned in Ernst and Ernst Analysis of Annual Reports (Abbott \& Monsen, 1979).

The four dimensions selected for the study are proxied by fifteen indicators shown in Table I below. We checked whether each firm has a positive record in each of the fifteen indicators. 
Table I

Set of indicators used to proxy the financial and social performance in sample firms

\begin{tabular}{|c|c|c|c|c|}
\hline Ser\# & Issue Area & Dimensions & Dimension/ Proxy & Indicators \\
\hline \multirow[t]{3}{*}{1.} & \multirow{3}{*}{$\begin{array}{l}\text { Financial } \\
\text { Performance }\end{array}$} & Profitability & Profitability & ROA=Net Income/Total Assets \\
\hline & & Profitability & Profitability & ROE=Net Income/Equity \\
\hline & & Profitability & Profitability & ROS=Net Income/Total Sales \\
\hline \multirow[t]{4}{*}{2.} & \multirow[t]{4}{*}{$\begin{array}{l}\text { Social } \\
\text { Responsibility/ } \\
\text { Performance }\end{array}$} & $\begin{array}{l}\text { Customers and } \\
\text { Suppliers }\end{array}$ & $\begin{array}{l}\text { Attention to } \\
\text { customers and } \\
\text { suppliers }\end{array}$ & $\begin{array}{l}\text { - Product safety and quality } \\
\text { disclosures } \\
\text { - Long-term partnerships }\end{array}$ \\
\hline & & $\begin{array}{l}\text { Human } \\
\text { resources }\end{array}$ & $\begin{array}{l}\text { Attention to the } \\
\text { staff }\end{array}$ & $\begin{array}{l}\text { - Training } \\
\text { - Employee health and safety } \\
\text { - Positive labor union } \\
\text { - Nondiscrimination and equal } \\
\text { opportunity } \\
\text { - Profit-sharing scheme }\end{array}$ \\
\hline & & $\begin{array}{l}\text { Community } \\
\text { and society }\end{array}$ & $\begin{array}{l}\text { Local community } \\
\text { Advantage } \\
\text { (Philanthropic } \\
\text { activities) }\end{array}$ & $\begin{array}{l}\text { - Relationship with community } \\
\text { - Public health services } \\
\text { - Educational services } \\
\text { - Community support programs }\end{array}$ \\
\hline & & Environment & $\begin{array}{l}\text { Attention to the } \\
\text { natural } \\
\text { environment }\end{array}$ & $\begin{array}{l}\text { - Pollution and/or noise control } \\
\text { - Environmentally sound } \\
\text { resource use } \\
\text { - Repair of environment } \\
\text { - Recycling of waste materials }\end{array}$ \\
\hline
\end{tabular}

We rated the companies on the indicated variables using a binary system. If the company meets the criteria, it scores " 1 "; otherwise, it scores " 0 ". At last, a company's total CSR score for a year was determined by summing all the values gathered. For example, a firm that implements recycling programs and demonstrates concern for the environment in its day-to-day operations, was regarded as having a positive record along the environmental dimension. A firm that actively promotes nondiscrimination and equal opportunity policy received a similar positive score along the human resources dimension.

We have borrowed concepts from previous studies concerning the rating scale and determination of total CSR score of a firm. The CSR indicators of Karagiorgos (2010, pp. 94-95) were rated on a scale from 0 to 3 . When a company does not take into account the specific indicator at all, it is rated with 0 . A company is ranked with 1 or 2 depending on the broadness of the description. The company is rated with 3 if it takes the indicator into 
consideration with a satisfying description. Finally, the author computed a compound CSR score for the analysis by adding both scores (social and environmental perspectives) for each company. The MSCI ESG Index used binary codes to measure CSR initiatives employed by companies (Waddock \& Graves, 1997). Mwangi and Jerotich (2013 p. 85) determined the total CSR score of firms by adding the scores for the five components - Community, Environment, Staff, Product and Customer - they considered in their study. In our study we rated the indices using a binary system (0 and 1) and the total CSR score was calculated by summing all the values gathered from the 15 indicators representing the four CSR perspectives.

\section{Dependent and Independent Variables}

In this study the dependent variable is CFP, which is indicated by ROA, ROE, and ROS and the independent variables are CSR Score, Firm Size, and Leverage. Past studies suggest that company size and risk (leverage) affect both firm financial performance and CSR (for instance, see Ullmann, 1985; McWilliams \& Siegel, 2000; and Orlitzky, 2001). So, firm size and leverage variables are controlled for in this study. Besides, we followed the suggestion of McWilliams and Siegel (2000) that R\&D costs should be included as another control variable in CSR-CFP study. At first we had included the variable in the regression model. However, since the firms we sampled did not have a record for R\&D costs, we dropped the variable from the model altogether.

Size is an important control variable because large firms may both exhibit greater financial performance and engage in more socially responsible activities as they tend to have more resources to dedicate to CSR programs than smaller firms (Udayasankar, 2008). Also, the risk tolerance of management needs to be controlled for since it influences decision making. For this study, company size is measured using total assets and risk is measured using total debt to total assets ratio.

\section{Model Specification}

In this study a multiple regression model was established to determine the relationship between the dependent and independent variables. Control variables of firm size and leverage were introduced in the regression model as explained below:

$$
C F P=\beta_{0}+\beta_{1} X_{1}+\beta_{2} X_{2}+\beta_{3} X_{3}+\varepsilon
$$

\section{Where:}


- CFP- Corporate financial performance (as measured by ROA, ROE, and ROS).

- $\beta_{0}$ - Constant; which would be equal to the mean if all slope coefficients are 0.

- $\mathrm{X}_{1}$ - CSR score (sum of firm CSR practice indexes).

- $\mathrm{X}_{2}$ - Total Assets (ln Total Assets).

- $\mathrm{X}_{3}$ - Leverage (Total Debt/Total Assets).

- $\beta_{1}, \beta_{2}$ and $\beta_{3}$ - Regression coefficients associated with each independent variable.

- $\varepsilon$ - Error term.

\section{Method of Data Analysis}

The collected CSR data were edited, coded, and classified into different components to facilitate a better and efficient analysis. The CFP data were also coded and entered into SPSS software package for analysis. Then similar to previous studies, correlation method was used to examine the relationship between CSR initiatives and financial performance (e.g., Brancoa \& Rodrigues, 2008; Lungu, Caraiani, \& Dascalu, 2011; Carnevale, Mazzuca, \& Venturini, 2012; and Andreaus, Costa, Pesci, \& Taufer, 2013). In addition, by running regression the association and the sign of relationship between the dependent and independent variables were computed (e.g., Barako \& Brown, 2008; Akinpelu, Ogunbi, Olaniran, \& Ogunseye, 2013; and Sharma, 2013). The coefficient of determination, $\mathrm{R}$ squared, measure was used to test the significance of the regression model in explaining the relationship between CSR actions and CFP. Besides, the $P$-value and the t-test were used to check the individual significance of the predictor variables used in the study.

\section{Emprical results and Discussion}

In this study we used the Pearson correlation and regression methods to analyze the relationship between corporate social responsibility and financial performance in the surveyed firms. These analyses are presented in this section . First of all, let us present the descriptive statistics of respondents and study variables.

\section{Descriptive statistics of respondents and variables}

\section{i. Respondent profile}

Data was obtained from 34 private manufacturing firms using questionnaire. The questionnaire was filled in by respondents from Accounting and Finance 
department or Administration department of each firm surveyed in this study. Annex 1 shows the respondents' profile.

Regarding age, $76.5 \%$ of the respondents were 20 up to 40 years old; $14.7 \%$ of them were 41 up to 60 years old; and $8.8 \%$ of them exceeded 60 years of age. Thus almost $77 \%$ of the respondents participated in this research were 40 years old and below. In terms of gender, $67.6 \%$ of the respondents were males and $32.4 \%$ were females. We observed that lots of male respondents participated in this study. In addition, their education level was $29.4 \%$ diploma; $52.9 \%$ bachelor degree; $8.8 \%$ master's degree; and again $8.8 \%$ either $10^{\text {th }}$ or $12^{\text {th }}$ grade. So, the majority of the respondents were college/university graduates.

Regarding their service in the firm, $64.7 \%$ of the respondents have been with their firms for 1 up to 5 years and $35.3 \%$ of them for above 5 years. Besides, $47.1 \%$ of the respondents work in Accounting \& Finance department and $52.9 \%$ in Administration department of the firms. We mentioned the departments where the respondents work to tell readers where we have collected the data from. Since the questionnaire is a recall-based questionnaire we need to get appropriate personnel to answer the questions. Aupperle et al. (1985) stated that they gathered CSP data through the surveying of 241 CEOs. Waddock and Graves (1997) mentioned that the MSCI ESG Index administered CSR questionnaires to corporations' investor relations office. We found in our study that people from the stated departments were more appropriate to fill in the questionnaires for they have good knowledge to respond to the CSR related questions. We assumed those people are with enough information and expertise to answer the questions truthfully. Generally, the results reveal that the respondents were appropriate in terms of age, gender, education, working experience and qualification to provide us with the data required for the study.

\section{ii. Company profile}

A total of 34 firms were surveyed in this study. We contacted $22(64.7 \%)$ firms located at Mekelle City and the remaining 2 (5.9\%), 4 (11.8\%), 5 (14.7\%), and $1(2.9 \%)$ firms located, respectively, at Western, Central, Eastern and Southern zones of Tigray Regional State. As Mekelle City hosts numerous manufacturing firms in the region, the majority of the sample was taken from this city. Table II provides a listing of the five sub-sectors that make up the 34 firms in the sample and the average CSR score for each sub-sector. 
TABLE II

CSR scores of sub-sectors in sample

\begin{tabular}{|l|r|r|r|r|r|r|}
\hline \multicolumn{1}{|c|}{ Sub-sector } & N & Percent & $\begin{array}{r}\text { CSR score } \\
\text { (a total of } \\
\text { 15 base } \\
\text { points) }\end{array}$ & Min & Max & \multicolumn{1}{c|}{$\begin{array}{c}\text { CSR } \\
\text { score } \\
\text { (percent) }\end{array}$} \\
\hline $\begin{array}{l}\text { Chemical \& Construction } \\
\text { Materials }\end{array}$ & 14 & 41.2 & 10.21 & 7 & 13 & $19 \%$ \\
\hline Cotton, Textile \& Garment & 1 & 2.9 & 9.00 & 9 & 9 & $16 \%$ \\
\hline $\begin{array}{l}\text { Food, Beverage \& } \\
\text { Pharmaceuticals }\end{array}$ & 12 & 35.3 & 11.17 & 7 & 13 & $21 \%$ \\
\hline Leather \& Leather Products & 2 & 5.9 & 12.00 & 12 & 12 & $22 \%$ \\
\hline Metal \& Engineering & 5 & 14.7 & 12.20 & 11 & 13 & $23 \%$ \\
\hline Total & $\mathbf{3 4}$ & $\mathbf{1 0 0 . 0}$ & $\mathbf{5 4 . 5 8}$ & & & $\mathbf{1 0 0 \%}$ \\
\hline
\end{tabular}

Source: survey, 2015

As can be seen in the table, the surveyed firms were engaged in the manufacture of chemical \& construction materials (41.2\%); food, beverage \& pharmaceuticals (35.3\%); metal \& engineering materials $(14.7 \%)$; leather \& leather products $(5.9 \%)$; and cotton, textile \& garment $(2.9 \%)$. Therefore, the majority of firms included in this study were manufacturer of chemical \& construction materials and only one firm was engaged in cotton, textile \& garment manufacturing. Since the main objective of the study is to establish the relationship between CSR and FP of manufacturing firms on the whole, industry type (type of sub-sector) has no implication in establishing the CSRFP link.

Besides, the table shows that there is a focus on CSR in the surveyed firms and the scores differ across sub-sectors. Consequently, metal \& engineering industry scored the highest CSR points (12.2 score or 23\%), while cotton, textile \& garment manufacturing industry scored the lowest points (9 score or $16 \%$ ). Higher CSR score indicates a better rating and lower score a lower one. The variation in the score reveals that some sub-sectors have made CSR initiatives better than others. 


\section{CSR and Financial Performance of Manufacturing Companies}

In addition, results show that the sampled firms were engaged in different CSR components. The study finds that most firms focus on their customers and suppliers $(31 \%)$, followed by welfare activities that target the work force (27\%). The environmental concerns are the next component of CSR activities (23\%). The least undertaken activities are those targeted at the local community (19\%). Table III shows the different components of CSR related activities performed by the firms.

TABLE III

CSR Activities undertaken by firms in manufacturing sector

\begin{tabular}{|c|c|c|c|c|c|c|}
\hline \multirow[b]{2}{*}{ Sub-sector } & \multicolumn{4}{|c|}{ CSR Dimensions } & \multicolumn{2}{|c|}{ Total CSR } \\
\hline & $\begin{array}{l}\text { Customers } \\
\quad \text { and } \\
\text { Suppliers (2 } \\
\text { base points) }\end{array}$ & $\begin{array}{l}\text { Staff }(5 \\
\text { base } \\
\text { points })\end{array}$ & $\begin{array}{c}\text { Local } \\
\text { Community } \\
(4 \text { base } \\
\text { points }) \\
\end{array}$ & $\begin{array}{c}\text { Natural } \\
\text { Environment } \\
(4 \text { base } \\
\text { points })\end{array}$ & Score & Percent \\
\hline $\begin{array}{l}\text { Chemical \& } \\
\text { Construction Materials }\end{array}$ & 1.93 & 3.64 & 1.79 & 2.86 & 10.22 & $19 \%$ \\
\hline $\begin{array}{l}\text { Cotton, Textile \& } \\
\text { Garment }\end{array}$ & 2.00 & 4.00 & 1.00 & 2.00 & 9.00 & $16 \%$ \\
\hline $\begin{array}{l}\text { Food, Beverage \& } \\
\text { Pharmaceuticals }\end{array}$ & 1.83 & 4.08 & 2.58 & 2.67 & 11.16 & $21 \%$ \\
\hline $\begin{array}{l}\text { Leather \& Leather } \\
\text { Products }\end{array}$ & 1.50 & 4.00 & 3.00 & 3.50 & 12.00 & $22 \%$ \\
\hline Metal \& Engineering & 2.00 & 4.40 & 3.00 & 2.80 & 12.20 & $23 \%$ \\
\hline Total CSR score (a) & 9.26 & 20.12 & 11.37 & 13.83 & 54.58 & $100 \%$ \\
\hline $\begin{array}{l}\text { Maximum expected } \\
\text { CSR score (b) }\end{array}$ & $\begin{array}{r}2 * 5=10 \\
\text { points }\end{array}$ & $\begin{array}{r}5 * 5=25 \\
\text { points }\end{array}$ & $\begin{array}{r}4 * 5=20 \\
\text { points }\end{array}$ & $\begin{array}{r}4 * 5=20 \\
\text { points }\end{array}$ & $\begin{array}{r}75 \\
\text { points }\end{array}$ & \\
\hline $\begin{array}{l}\text { CSR score per CSR } \\
\text { dimension }(c=a / b)\end{array}$ & 0.93 & 0.80 & 0.57 & 0.69 & 2.99 & \\
\hline $\begin{array}{l}\text { Percentage of CSR } \\
\text { focus by firm } \\
(\mathrm{d}=\mathrm{c} / 2.99)\end{array}$ & $31 \%$ & $27 \%$ & $19 \%$ & $23 \%$ & $100 \%$ & \\
\hline
\end{tabular}

Source: Survey, 2015

As we can observe from Table III, each sub-sector in the manufacturing sector differs in its focus on the concept of CSR. Some firms singled out certain CSR component, while others preferred to integrate different CSR concepts in to all aspects of their business practices. This may be due to difference in objectives and corporate values of the firms.

The findings reveal that the surveyed firms give top priority to their customers and suppliers. This supports the business practice that the better a firm can manage the relationships it has with its customers the more successful it will 
become as it gains business benefits from its customers and gets continuous supply of raw materials and accessories from its suppliers. Also, the firms have experienced productivity of employees because of their commitment to improve working conditions and labor practices. Studies show that firms actually benefit from socially responsible actions in terms of employee morale and productivity (Moskowitz, 1972).

However, the firms give less attention to being a partner in improving the health and welfare of the communities surrounding them. The firms should recognize that assisting the society through health, education and community services helps them sustain their business. By holding a holistic view of itself in relation to its stakeholders a socially responsible firm should measure its performance "via a triple bottom-line: economic/financial, environmental, and social', (Werner, 2009, p. 546).

\section{iii. Descriptive statistics of variables}

The variables used in this study consist of dependent variable and independent variable. The dependent variables are ROA, ROE, and ROS and the independent variables include CSR score, firm size, and leverage. Table IV provides the descriptive statistics for the variables used in the study.

TABLE IV

Descriptive statistics for CSR score and other variables

\begin{tabular}{|l|r|r|r|r|r|}
\hline \multicolumn{7}{|c|}{ Descriptive Statistics } \\
\hline & $\mathbf{N}$ & $\begin{array}{c}\text { Minimu } \\
\text { m }\end{array}$ & $\begin{array}{r}\text { Maximu } \\
\text { m }\end{array}$ & Mean & $\begin{array}{c}\text { Std. } \\
\text { Deviation }\end{array}$ \\
\hline CSRscore & 34 & 7.00 & 13.00 & $\mathbf{1 0 . 9 1 1}$ & 1.76442 \\
\hline ROA & 34 & -.20 & .77 & $\mathbf{. 0 7 5 0}$ & .18914 \\
\hline ROE & 34 & -.47 & .77 & $\mathbf{. 1 0 8 4}$ & .30621 \\
\hline ROS & 34 & -.45 & .50 & $\mathbf{. 0 1 2 9}$ & .21942 \\
\hline Firmsize & 34 & 13.38 & 19.61 & $\mathbf{1 6 . 4 4 9}$ & 1.31794 \\
\hline Leverage & 34 & .00 & .86 & $\mathbf{. 4 0 8 4}$ & .27815 \\
\hline
\end{tabular}

Source: Survey, 2015

The average CSR score of the firms operating in various sub-sectors was 10.91 base points, which is equivalent to 73 percent, compared to the maximum of 15 
base points. The figure shows that the firms have been familiar with CSR programs for the surveyed period. Nevertheless, the firms need to exert extra efforts to raise this average point further, because more CSR score has direct implication on the firms' financial performance (see the correlation analysis below).

The natural logarithm of the average total assets of the firms, rounded to two decimal places, was 16.45. This is equivalent to Birr 13,936,195 of investment made in firm assets. In addition, the table shows that the firms earned Birr 0.08 from additional Birr 1 of investment made in assets and Birr 0.11 from Birr 1 contribution made by equity investors. Also, sales for Birr 1 produced a Birr 0.01 of additional return to the firms.

The debt to asset ratio of the firms was on average 0.41 , indicating a Birr 0.41 loan claims made against Birr 1 of total assets. This figure shows higher leverage level as creditors have supplied $41 \%$ of the assets owned by the firms.

\section{Correlation Analysis}

The study tested the relationship between CSR and CFP of firms using correlation analysis. Table $\mathrm{V}$ provides the correlation matrices for the key variables. 
TABLE V

Correlation matrices for variables

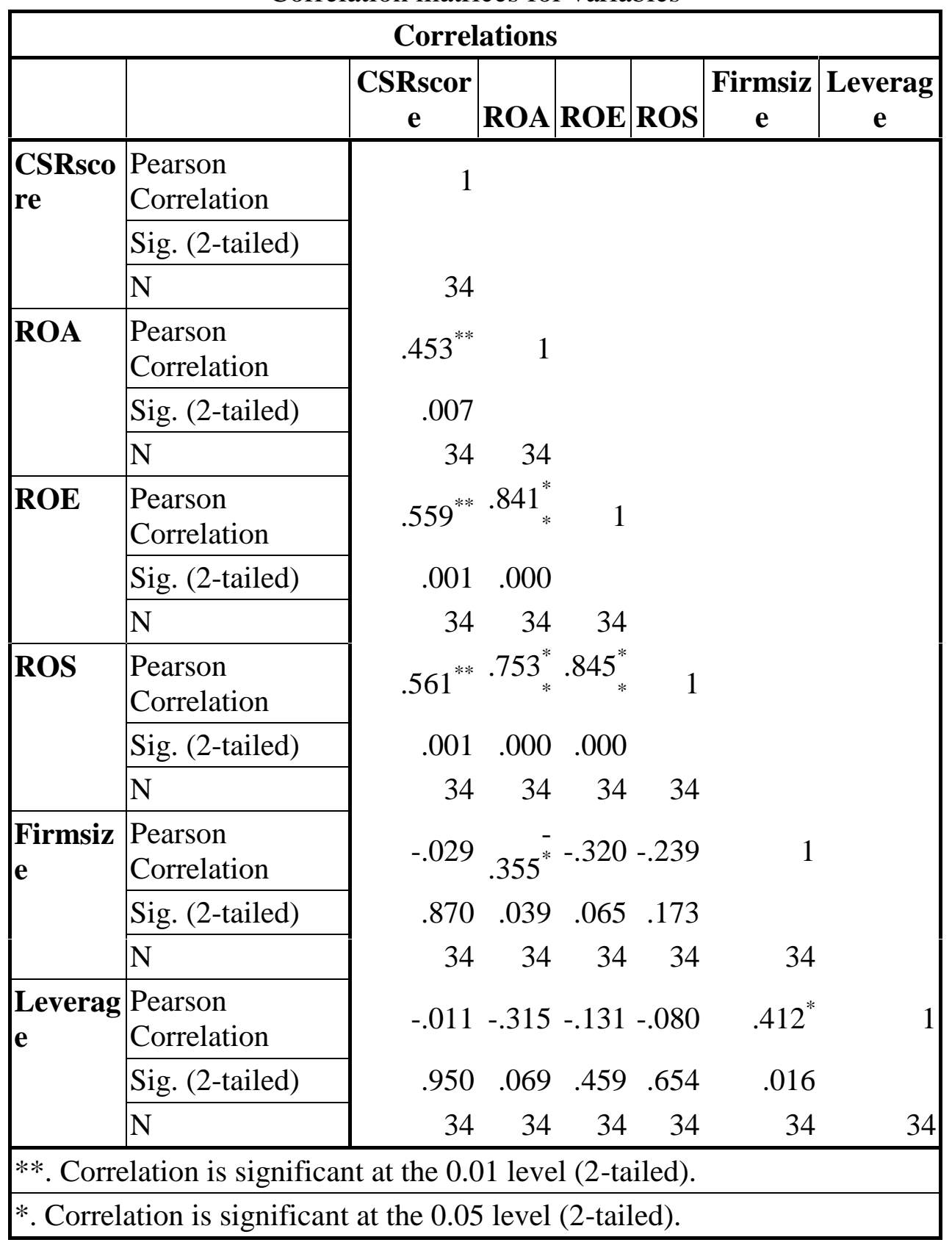

EJBE Vol. 5 No. 2/2015 
Source: Survey, 2015

Table V reveals that at the $p<0.01$ level of significance ROA, ROE and ROS tend to be positively associated with corporate social responsibility $(.453, .559$, and .561, respectively). This finding reveals that firms high in social responsibility experience higher financial performance (ROA, ROE and ROS) and those with low social responsibility earn lower financial returns. The result is consistent with previous studies that have concluded that CSR investments reap better financial returns to organizations (e.g., McWilliams \& Seigel, 2000 and Orlitzky et al., 2003).

The positive association between the financial performance indicators and corporate social responsibility supports the view that, through its effects on various stakeholders, social responsibility generates better financial performance for a firm (Cornell \& Shapiro, 1987). We can observe that by providing a reputation insurance CSR activities lead to greater confidence among stakeholders in the firm, supporting the financial returns of the firm (Saeed \& Arshad, 2012). Due to commitment to CSR the firms can increase their sales revenue. In addition, they can attract and retain employees, which further lead them to reduced staff turnover and other associated costs (Turban \& Greening, 1997).

Besides, we argue that spending in CSR should be considered a strong link between a firm and its stakeholders. Engagement in CSR helps the firm build a positive image with diverse parties, such as customers, investors, and suppliers as stated by Fombrun and Shanley (1990). In addition, CSR helps a firm develop new competencies, resources, and capabilities, which all can enhance strong relationship between the firm and stakeholders (Wernerfelt, 1984; Barney, 1991; and Russo \& Fouts, 1997).

\section{Regression Analysis}

Regression analysis was used to test our hypothesis using financial performance as the dependent variable and CSR as the explanatory variable, controlling for firm size and debt level. As shown in Table V above, none of the predictor variables is strongly correlated with each other (no correlation coefficient $>0.8$ ). So, the model has passed the multicollinearity test. Thus it can be used in forecasting financial performance among the manufacturing firms. 
The regression model assessed whether CSR is linked to financial performance and determined in what direction the relationship exists. Table VI summarizes the regression results.

Table VI

Regression model summary

\begin{tabular}{|l|c|c|c|c|c|c|c|}
\hline Variable & $\begin{array}{c}\text { CSR } \\
\text { coefficient }\end{array}$ & $\begin{array}{c}\boldsymbol{p} \text {-value } \\
\text { of CSR }\end{array}$ & $\mathbf{R}$ & $\begin{array}{c}\mathbf{R} \\
\text { Square }\end{array}$ & $\begin{array}{c}\text { Adjusted } \\
\text { R Square }\end{array}$ & $\begin{array}{c}\boldsymbol{F} \text { - } \\
\text { statistic }\end{array}$ & $\begin{array}{c}\boldsymbol{p} \text {-value } \\
\text { of } \boldsymbol{F} \text { - } \\
\text { statistic }\end{array}$ \\
\hline ROA & .047 & .005 & .597 & .357 & .292 & 5.541 & .004 \\
\hline ROE & .096 & .000 & .637 & .405 & .346 & 6.811 & .001 \\
\hline ROS & .069 & .001 & .604 & .365 & .301 & 5.736 & .003 \\
\hline
\end{tabular}

Source: Survey, 2015

\section{i. ANOVA Test}

In Table VI the Analysis of Variance (ANOVA) result has provided $P$-value < 0.01 of $F$ - statistic for all three conditions, supporting the alternative hypothesis that there is a significant relationship between better financial performance and CSR initiative, firm size, and level of debt, against the null hypothesis that there is no significant relationship between these variables. Hence, ANOVA test shows the existence of correlation between the response and predictor variables. Therefore, based on those results of analyses we can conclude that there is a significant linear relationship between financial performance and CSR score, firm size, and leverage.

\section{ii. Test for the Significance of the Regression Model}

The correlation coefficient $(\mathrm{R})$ is used to check on the magnitude and the direction of the relationship between the independent and dependent variables. From Table VI we can observe correlation coefficient of 0.597 for ROA, 0.637 for ROE, and 0.604 for ROS. The results show a positive correlation between the dependent and independent variables.

The coefficient of determination ( $\mathrm{R}$ Square) of the study, which measures the extent to which the independent variables can predict the dependent variable, shows that $35.7 \%$ of the variation in ROA; $40.5 \%$ of the variation in ROE; and $36.5 \%$ of the variation in ROS are explained by the changes in CSR score, firm size, and leverage. The adjusted $\mathrm{R}$ square (of $29.2 \%, 34.6 \%$, and $30.1 \%$ ) also shows that the model is a fair estimate of the relationship between the 
dependent and independent variables. Therefore, the regression model obtained for this study can be used to forecast financial performance of the firms.

The regression analysis finds that CSR score of the firms in the survey has a significant positive relationship with financial performance at the $p<0.01$ level. The CSR coefficient reveals that a one unit increase in CSR base point leads a firm to an increase in ROA, ROE, and ROS by 4.7\%, 9.6\%, and $6.9 \%$, respectively. This indicates that higher CSR score would produce higher ROA, ROE, and ROS. This result supports the study hypothesis, which posits that commitment to CSR would produce better financial performance. The result is consistent with previous studies, such as Posnikoff (1997); Waddock and Graves (1997); Hill et al., (2007); Mwangi and Jerotich (2013); and Mujahid and Abdullah (2014).

CSR initiatives have become an advantage for the firms surveyed in this study. CSR programs can improve firm image, and thus the firms have benefitted from increased customer base. Also, CSR programs increase employee morale and productivity. Besides, since the firms show responsibility for their concerns the societies can build confidence in the firms. In addition, since the firms give due concern to the improvement of the natural environment where they operate their activities, they can attract the attitude of the government towards them. Overall, CSR initiatives are rewarding not only for stakeholders, but also for the financial success of the firms.

\section{Conclusions and Policy Implications}

Recently there have been studies carried out concerning corporate social responsibility. CSR is a concept about integrating the environmental and social concerns into the business strategy and everyday practice. This study attempts to address the question whether corporate social activity is linked to financial performance of privately owned manufacturing firms in Tigray Regional State, Ethiopia. Using correlation and regression methods, we tested the sign and magnitude of the relationship between CSR and CFP in 34 surveyed firms.

Using financial performance as the dependent variable and the CSR score as the independent variable, the study reveals that a positive correlation exists between CSR and CFP, which supports those studies that found positive linkages in the past. This result indicates that firms high in CSR experience achieve better financial benefits and those low in CSR experience achieve lower financial return.

EJBE Vol. 5 No. 2/2015

Page 235 
The regression analysis finds that CSR score of the firms in the survey has a significant positive relationship with financial performance at the $p<0.01$ level. The CSR coefficient reveals that a one unit increase in CSR base point leads a firm to an increase in ROA, ROE, and ROS by $4.7 \%, 9.6 \%$, and $6.9 \%$, respectively. This further indicates that higher CSR score would produce higher ROA, ROE, and ROS in the firms. This result supports the study hypothesis, which posits that commitment to CSR would generate better financial performance.

Overall, CSR initiatives have become rewarding not only for stakeholders, but for the financial success of the firms surveyed in this study. Therefore, firms should always be committed to pursue CSR promoting policy in their day to day business operations as increases in CSR investments can lead to higher CFP while balancing the needs of the staff, environment and the surrounding community at large. We propose implementation of the CSR concepts in all business operations of the firms.

On the other hand, we were not able to conduct content analysis in this study as the firms do not have the custom of recording CSR initiatives. The firms only tell about CSR related issues by recalling some transactions and events that happened in the past. Obviously, this challenges accurately determining the presence, nature and scope of CSR activities in the firms. To make things worse, in such situation some respondents might conceal their true opinions and instead answer what they think would please the researchers. Therefore, appropriate policy that requires CSR programs record and disclosure should be designed. This helps the firms document their CSR actions and reflect their devotion of' social accounting, which is the impact on the society and environment. Consequently, the firms would create higher social value that helps them achieve both reputation and financial success from internal and external stakeholders.

\section{Recommendation for Further Research}

KPMG "International Survey of Corporate Responsibility Reporting 2013" reported CSR activities in 100 largest companies across 41 countries. KPMG reporting system shows increasing trend of CSR activities in the entire world (Iqbal, Sarwat, Hasan et al, 2014). So far several studies have been conducted in the developed world to investigate the CSR-FP link. However, the concept of CSR as a common business practice has only recently established a foothold in developing countries, including Ethiopia. We have attempted to establish the 
relationship between CSR and FP drawing data from Tigray region of Ethiopia. The results of this study can be regarded as a preliminary discussion about the relationship between CSR performance and FP in the manufacturing firms operating in the region. In this study only companies operating in manufacturing sector were considered. We recommend a similar study may be conducted in other sectors as well. This will be useful in comparing CSR scores of different sectors in the economy. Also, such a study should be conducted in other regions to give a more complete picture of the result of CSR programs in the country. 
CSR and Financial Performance of Manufacturing Companies

\section{References}

Abbott, W.F. and Monsen, R.J. (1979). On the Measurement of Corporate Social Responsibility: Self-Reported Disclosures as a Method of Measuring Corporate Social Involvement. Academy of Management Journal, 22(3): 501-515.

Akinpelu, Y.A., Ogunbi, O.J., Olaniran, Y.A., and Ogunseye, T.O. (2013). Corporate Social Responsibility Activities Disclosure by Commercial Banks in Nigeria. European Journal of Business and Management, 5:173-185.

Andersen, M.L., and Olsen, L. (2011). Corporate social and financial performance: a canonical correlation analysis. Academy of Accounting and Financial Studies Journal, 15(2): 17-37.

Andreaus, M., Costa, E., Pesci, C., and Taufer, E. (2013). The Interaction Between Industry- specific Standards and Corporate Social Reporting. Empirical Evidence from Cooperative Banks in Italy. 36 EAA Annual Congress, 1-49.

Aragón-Correa, J.A, and Rubio-López, E.A. (2007). Proactive Corporate Environmental Strategies: Myths and Misunderstandings. Long Range Planning, 40(3), 357-381.

Aupperle, K. E., Carroll, A.B, and Hatfield, J.D. (1985). An empirical examination of the relationship between corporate social responsibility and profitability. Academy of Management Journal, 28 (2): 446-463.

Aupperle, K. E. (1991). The Use of Forced Choice Survey Procedures in Assessing Corporate Social Orientation. In J. E. Post (Ed.), Research in Corporate Social Performance and Policy, 12: 269-280.

Barako, D.G. and Brown, A.M. (2008). Corporate Social Reporting and Board Representation: Evidence from the Kenyan Banking Sector. Journal of Management \& Governance, 12 (4): 309-324.

Barney, J. (1991). Firm resource and sustained competitive advantage. Journal of Management 17(1): 99-120.

Bedada, S.M. and Eshetu, M.S. (2011). Ethiopian Floriculture Industry from Corporate Social Responsibility (CSR) \& Governance Perspective. Business Administration Master's Thesis, Karlstad Business School, Sweden (Unpublished). Retrieved from: http://www.divaportal.se/smash/get/diva2:424399/FULLTEXT01.pdf. Boddy, D. (2008). Management, An Introduction, Fourth Edition, Prentice Hall.

Brancoa, M.C. and Rodrigues, L.L. (2008). Social Responsibility Disclosure: 
CSR and Financial Performance of Manufacturing Companies

A Study of Proxies for the Public Visibility of Portuguese Banks. The British Accounting Review, 40(2): 161-181.

Brown, B. and Perry, S. (1994). Removing the financial performance halo from Fortune's Most Admired Companies. Academy of Management Journal 37: 1346-1359.

Bryman, A. (2008). Social Research Methods, Third Edition, Oxford University Press.

Carnevale, C., Mazzuca, M., and Venturini, S. (2012). Corporate Social Reporting in European Banks: The Effects on a Firm's Market Value. Corporate Social Responsibility and Environmental Management, 19 (3): 159-177.

Clarkson, M.B.E. (1995). A stakeholder framework for analyzing and evaluating corporation social performance. Academy of Management Review, 20(1).

Cochran, P.L. and Wodd, R.A. (1984). Corporate Social Responsibility and Financial Performance. Academy of Management Journal, 27(1), 42-56.

Cordeiro, J.J. and Sarkis, J. (1997). Environmental proactivism and firm performance: evidence from security analyst earnings forecasts. Business Strategy and the Environment, 6(2), 104-114.

Cornell, B. and Shapiro, A. (1987). Corporate stakeholders and corporate finance. Financal Management, 16: 5-14.

Demsetz, H. and Villalonga, B. (2001) Ownership Structure and Corporate Performance. Journal of Corporate Finance 7, 209-233.

Fombrun, C. And Shanley, M. (1990) What's in a name? Reputation building and corporate $\quad$ strategy. Academy of Management Journal, 33(2): 233 -258 .

Ghrmay, T.M. (2013). The Nature of Corporate Social Responsibility (CSR) in Ethiopian Business Context. Available at SSRN: http://ssrn.com/abstract=2462800.

Giannarakis, G., Litinas, N., and Theotokas, I. (2009). Characteristics of Corporate Social Responsibility Indicators. World Academy of Science, Engineering and Technology International Journal of Social, Management, Economics and Business Eng., 3(6).

Gray, R.H., Dillard, J., and Spence, C. (1996). Social accounting as if the world matters: an essay in postalgia and a new absurdism. Public Management Review, 11(5): 545-73.

Griffin, J. J. and Mahon, J.F. (1997). The Corporate Social Performance and Corporate Financial Performance Debate: Twenty-Five Years of Incomparable Research. Business Society 36(1): 5-31.

Hill, I. (2006). How Finance Can Help Move CSR up the Agenda. The Cost 
CSR and Financial Performance of Manufacturing Companies

and Management, 34(6): 5-9.

Hill, R.P., Ainscough, T., Shank, T., and Manullang, D. (2007). Corporate

Social Responsibility and Socially Responsible Investing: A Global

Perspective. Journal of Business Ethics, 70(2):165-174.

Igalens, J., and Gond, J.P. (2005). Measuring Corporate Social Performance in France: a critical and empirical analysis of ARESE data. Journal of Business Ethics, 56(2): 131-48.

Iqbal, D., Sarwat, S., Hasan, S., Baloch, A., and Salim, U. (2014). To Be Responsible Socially Is Viable Financially. European Scientific Journal, 10(28):427-447; ISSN: 1857 - 7881 (Print) e - ISSN 18577431.

Karagiorgos, T. (2010). Corporate Social Responsibility and Financial Performance: An Empirical Analysis on Greek Companies. European Research Studies, XIII(4): 85- 108.

Lopez, M., Garcia, A., and Rodriguez, L. (2007). Sustainable development and corporate performance: A study based on the Dow Jones Sustainability Index. Journal of Business Ethics, 75: 285-300.

Lungu, C.I., Caraiani, C., and Dascalu, C. (2011). Research on Corporate Social Responsibility Reporting. Corporate Social Responsibility, 29: 117 $-131$.

Mahoney, L., and Roberts, R.W. (2007). Corporate Social Performance, Financial Performance and Institutional Ownership in Canadian Firms. Accounting Forum, 31:233-253.

Margolis, J. D. and Walsh, J. P. (2003). Misery Loves Companies: Rethinking Social Initiatives by Business. Administrative Science Quarterly 48(2): 268-305.

McWilliams, A. and Siegel, D. (2000). Corporate social responsibility and financial performance: Correlation or misspecification? Strategic Management Journal, 21(5): 603-609.

McWilliams, A. and Siegel, D. (2001). Corporate social responsibility: A theory of the firm perspective. Academy of Management Review, 26 (1): 117-127.

Mishra, S. and Suar, D. (2010). Does Corporate Social Responsibility Influence Firm Performance of Indian Companies? Journal of Business Ethics, 95:571-601. DOI 10.1007/s10551-010-0441-1.

Moskowitz, M. (1972). Choosing Socially Responsible Stocks. Business and Society Review, 1: 71-75.

Mujahid, M. and Abdullah, A. (2014). Impact of Corporate Social Responsibility on Firms Financial Performance and Shareholders Wealth. European Journal of Business and Management, 6(31).

EJBE Vol. 5 No. 2/2015 
Mwangi, C.I. and Jerotich, O.J. (2013). The Relationship between Corporate Social Responsibility Practices and Financial Performance of Firms in the Manufacturing, Construction and Allied Sector of the Nairobi Securities Exchange. International Journal of Business, Humanities and Technology, 3(2), 81-90.

Orlitzky, M. (2001). 'Does Organizational Size Confound the Relationship between Corporate Social Performance and Firm Financial Performance?' Journal of Business Ethics, $33(2)$ : 167-80.

Orlitzky, M., Schmidt, F.L., and Rynes, S. (2003). Corporate social and financial performance: A meta-analysis. Organization Studies, 24 (3): 403-411.

Piatti, D. (2014). Italian Mutual Banks: Corporate Social and Financial Performance. European Scientific Journal, 10 (4), 1-16.

Posnikoff, J. (1997). Disinvestment from South Africa: They did well by doing good. Contemporary Economic Policy, 15(1): 76-86.

Potluri, R,M. and Temesgen, Z. (2008). Corporate social responsibility: an attitude of Ethiopian corporates. Social Responsibility Journal, 4(4): 456 $-463$.

Preston, L.E. and O'Bannon, D.P. (1997). The Corporate Social-Financial Performance Relationship: A Typology and Analysis. Business and Society 36: 419-429.

Robertson, D.C. (2009). Corporate Social Responsibility and Different Stages of Economic Development: Singapore, Turkey, and Ethiopia. Journal of Business Ethics, 88:617- 633, DOI 10.1007/s10551-009-0311-x.

Russo, M.V. and Fouts, P.A. (1997). A resource-based Perspective on Corporate Environmental Performance and Profitability. Academy of Management Journal, 40: 534-559.

Saeed, M. M. and Arshad, F. (2012). Corporate social responsibility as a source of competitive advantage: The mediating role of social capital and reputational capital. Database Marketing \& Customer Strategy Management, 19(4):219-232.

Sapkauskiene, A., and Leitoniene, S. (2014). Corporate Social Responsibility Research Methods Analysis. European Scientific Journal, volume 1.

Sharma, N. (2013). Web-based Disclosures and Their Determinants: Evidence from Listed Commercial Banks in Nepal. Accounting and Finance Research, 2(3): 1-13.

Simerly, R.L. (2003). Empirical Examination of the relationship between Management and Corporate Social Performance. International Journal of Management, 20(3): 353-359.

Simpson, W.G., and Kohers, T. (2002). The link between corporate social and 
CSR and Financial Performance of Manufacturing Companies

financial performance: Evidence from the banking industry. Journal of Business Ethics, 35(2): 97-109.

Soana, M.G. (2009). The relationship between corporate social performance and corporate financial performance in the banking sector. Working Paper Series, Available at $\quad$ SSRN: http://ssrn.com/abstract=1325956.

Tilahun, A. (2011). Corporate Social Responsibility in Sustainable Environmental Management in Ethiopia; A study of selected corporations and enterprises, School of Graduate Studies, AAU. Unpublished. Retrieved from: http://www.slideshare.net/Costantinos/corporatesocial-responsibility-in- sustainable-environmental-management.

Turban, D.B., and Greening, D.W. (1997). Corporate Social Performance and Organizational Attractiveness to Prospective Employee. Academy of Management Journal, 40(3), 65-79.

Udayasankar, K. (2008). Corporate social responsibility and firm size. Journal of Business Ethics, 83: 167-175.

Ullmann, A. (1985). Data in search of a theory: A critical examination of the relationship among social performance social disclosure, and economic performance. Academy of Management Review, 10, 540-577.

Waddock, S.A., and Graves, S.B. (1997). The Corporate Social Performance -Financial Performance link. Strategic Management Journal, 18(4), 303 -319 .

Wagner, M., Van, P. N., Azomahou, T., and Wehrmeyer, W. (2002). The relationship between the environmental and economic performance of firms: an empirical analysis of the European paper industry.

Corporate Social Responsibility and Environmental Management, 9 (3), 133-146.

Welch, I. and Wazzan, C. (1999). The effect of socially activist investment policies on the financial markets: Evidence from South African boycott. Journal of Business, 72(1): $\quad$ 35-89.

Werner, W.J. (2009). Corporate Social Responsibility Initiatives Addressing Social Exclusion in Bangladesh. Journal of Health, Population, and Nutrition, 27(4): 545-562.

Wernerfelt, B. (1984) A resource-based view of the firm. Strategic Management Journal 5: 171-180.

Withisuphakorn, P. and Jiraporn, P. (2015). The effect of firm maturity on corporate social responsibility (CSR): do older firms invest more in CSR? Applied Economics Letters, 23(4): 298-301. DOI: 10.1080/13504851.2015.1071464.

Wright, P. and Ferris, S. (1997). Agency conflict and corporate strategy: The effect of divestment on corporate value. Strategic Management Journal, 
CSR and Financial Performance of Manufacturing Companies

18(1): 77-83.

Wolfe, R. (1991). The Use of Content Analysis to Assess Corporate Social Responsibility. In J. E. Post (Ed.), Research in Corporate Social Performance and Policy, 12: 281-308.

Yang F.J., Lin, C.W., and Chang, Y.N. (2010). The linkage between corporate social performance and corporate financial performance. African Journal of Business Management, 4(4): 406-413.

Yoshikawa, T. and Phan, P.H. (2003). The performance implications of ownership-driven governance reform. European Management Journal, 21: 698-706.

Zapciu, R.M. and Hurduzeu, G. (2015). Corporate Social Responsibility and its Financial Performance. The Romanian Economic Journal, Year XVIII no. 56: 201-213. 
CSR and Financial Performance of Manufacturing Companies

Annexes

Annex 1: Demographic characteristics of respondents

\begin{tabular}{|c|c|c|c|c|c|}
\hline \multicolumn{6}{|c|}{ 1) Respondent's age } \\
\hline & & Frequency & Percent & $\begin{array}{l}\text { Valid } \\
\text { Percent }\end{array}$ & $\begin{array}{c}\text { Cumulative } \\
\text { Percent }\end{array}$ \\
\hline \multirow[t]{21}{*}{ Valid } & 23 & 1 & 2.9 & 2.9 & 2.9 \\
\hline & 24 & 1 & 2.9 & 2.9 & 5.9 \\
\hline & 25 & 1 & 2.9 & 2.9 & 8.8 \\
\hline & 27 & 2 & 5.9 & 5.9 & 14.7 \\
\hline & 28 & 4 & 11.8 & 11.8 & 26.5 \\
\hline & 30 & 3 & 8.8 & 8.8 & 35.3 \\
\hline & 31 & 1 & 2.9 & 2.9 & 38.2 \\
\hline & 32 & 2 & 5.9 & 5.9 & 44.1 \\
\hline & 35 & 1 & 2.9 & 2.9 & 47.1 \\
\hline & 36 & 1 & 2.9 & 2.9 & 50.0 \\
\hline & 37 & 2 & 5.9 & 5.9 & 55.9 \\
\hline & 38 & 1 & 2.9 & 2.9 & 58.8 \\
\hline & 39 & 1 & 2.9 & 2.9 & 61.8 \\
\hline & 40 & 5 & 14.7 & 14.7 & 76.5 \\
\hline & 48 & 1 & 2.9 & 2.9 & 79.4 \\
\hline & 50 & 1 & 2.9 & 2.9 & 82.4 \\
\hline & 55 & 2 & 5.9 & 5.9 & 88.2 \\
\hline & 57 & 1 & 2.9 & 2.9 & 91.2 \\
\hline & 64 & 2 & 5.9 & 5.9 & 97.1 \\
\hline & 67 & 1 & 2.9 & 2.9 & 100.0 \\
\hline & Total & 34 & 100.0 & 100.0 & \\
\hline
\end{tabular}

EJBE Vol. 5 No. 2/2015 
CSR and Financial Performance of Manufacturing Companies

\begin{tabular}{|l|l|r|r|r|r|}
\hline \multicolumn{7}{|c|}{ 2) Respondent's gender } \\
\hline \multirow{3}{*}{} & & Frequency & Percent & $\begin{array}{c}\text { Valid } \\
\text { Percent }\end{array}$ & $\begin{array}{c}\text { Cumulative } \\
\text { Percent }\end{array}$ \\
\hline \multirow{3}{*}{\begin{tabular}{l} 
Valid \\
\cline { 1 - 6 }
\end{tabular}} & Female & 11 & 32.4 & 32.4 & 32.4 \\
\cline { 2 - 6 } & Male & 23 & 67.6 & 67.6 & 100.0 \\
\cline { 2 - 6 } & Total & 34 & 100.0 & 100.0 & \\
\hline
\end{tabular}

\begin{tabular}{|l|l|r|r|r|r|}
\hline \multicolumn{7}{|c|}{ 3) Respondent's education level } \\
\hline \multirow{3}{*}{} & & Frequency & Percent & $\begin{array}{c}\text { Valid } \\
\text { Percent }\end{array}$ & $\begin{array}{c}\text { Cumulative } \\
\text { Percent }\end{array}$ \\
\hline \multirow{7}{*}{ Valid } & 10 & 29.4 & 29.4 & 29.4 \\
\cline { 2 - 6 } & Diploma & 18 & 52.9 & 52.9 & 82.4 \\
\cline { 2 - 6 } & First degree & 3 & 8.8 & 8.8 & 91.2 \\
\cline { 2 - 6 } & Second degree & 3 & 8.8 & 8.8 & 100.0 \\
\cline { 2 - 6 } & Other & 34 & 100.0 & 100.0 & \\
\cline { 2 - 7 } & Total & & & & \\
\hline
\end{tabular}

\begin{tabular}{|c|c|c|c|c|c|}
\hline \multicolumn{6}{|c|}{ 4) Respondent's year of service in the firm } \\
\hline & & Frequency & Percent & $\begin{array}{c}\text { Valid } \\
\text { Percent }\end{array}$ & $\begin{array}{c}\text { Cumulative } \\
\text { Percent }\end{array}$ \\
\hline \multirow[t]{14}{*}{ Valid } & 1 & 2 & 5.9 & 5.9 & 5.9 \\
\hline & 1.25 & 1 & 2.9 & 2.9 & 8.8 \\
\hline & 2 & 2 & 5.9 & 5.9 & 14.7 \\
\hline & 3 & 6 & 17.6 & 17.6 & 32.4 \\
\hline & 3.5 & 2 & 5.9 & 5.9 & 38.2 \\
\hline & 4 & 4 & 11.8 & 11.8 & 50.0 \\
\hline & 5 & 5 & 14.7 & 14.7 & 64.7 \\
\hline & 5.5 & 1 & 2.9 & 2.9 & 67.6 \\
\hline & 6 & 3 & 8.8 & 8.8 & 76.5 \\
\hline & 7 & 3 & 8.8 & 8.8 & 85.3 \\
\hline & 9 & 1 & 2.9 & 2.9 & 88.2 \\
\hline & 10 & 2 & 5.9 & 5.9 & 94.1 \\
\hline & 15 & 2 & 5.9 & 5.9 & 100.0 \\
\hline & Total & 34 & 100.0 & 100.0 & \\
\hline
\end{tabular}


CSR and Financial Performance of Manufacturing Companies

\begin{tabular}{|l|l|r|r|r|r|}
\hline \multicolumn{7}{|c|}{ 5) Occupation of the respondent } \\
\hline & & Frequency & Percent & $\begin{array}{c}\text { Valid } \\
\text { Percent }\end{array}$ & $\begin{array}{l}\text { Cumulativ } \\
\text { e Percent }\end{array}$ \\
\hline \multirow{3}{*}{ Valid } & $\begin{array}{l}\text { Accounting } \\
\text { profession }\end{array}$ & 16 & 47.1 & 47.1 & 47.1 \\
\cline { 2 - 6 } & $\begin{array}{l}\text { Managemen } \\
\text { t profession }\end{array}$ & 18 & 52.9 & 52.9 & 100.0 \\
\cline { 2 - 6 } & Total & 34 & 100.0 & 100.0 & \\
\hline
\end{tabular}

Annex 2: Regression Results

\section{A) Dependent Variable: ROA}

\begin{tabular}{|c|c|c|c|c|}
\hline \multicolumn{5}{|c|}{ Model Summary } \\
\hline Model & $\mathrm{R}$ & R Square & $\begin{array}{c}\text { Adjusted R } \\
\text { Square }\end{array}$ & Std. Error of the Estimate \\
\hline 1 & $.597^{\mathrm{a}}$ & .357 & .292 & .15913 \\
\hline
\end{tabular}

\begin{tabular}{|c|c|c|c|c|c|c|}
\hline \multicolumn{7}{|c|}{ ANOVA $^{b}$} \\
\hline \multicolumn{2}{|c|}{ Model } & $\begin{array}{l}\text { Sum of } \\
\text { Squares }\end{array}$ & $\mathrm{df}$ & Mean Square & $\mathrm{F}$ & Sig. \\
\hline \multirow[t]{3}{*}{1} & Regression & .421 & 3 & .140 & 5.541 & $.004^{\mathrm{a}}$ \\
\hline & Residual & .760 & 30 & .025 & & \\
\hline & Total & 1.181 & 33 & & & \\
\hline \multicolumn{5}{|c|}{$\begin{array}{l}\text { a. Predictors: (Constant), Leverage, CSRscore, } \\
\text { Firmsize }\end{array}$} & & \\
\hline \multicolumn{3}{|c|}{ b. Dependent Variable: ROA } & & & & \\
\hline
\end{tabular}

\section{Coefficients $^{\mathrm{a}}$}

\begin{tabular}{|l|l|r|r|r|r|r|}
\hline \multicolumn{2}{|l|}{} & \multicolumn{2}{|c|}{$\begin{array}{c}\text { Unstandardized } \\
\text { Coefficients }\end{array}$} & $\begin{array}{l}\text { Standardized } \\
\text { Coefficients }\end{array}$ & & \\
\cline { 3 - 8 } Model & \multicolumn{1}{|c|}{ B } & Std. Error & \multicolumn{1}{|c|}{ Beta } & \multicolumn{1}{c|}{$\mathrm{t}$} & \multicolumn{1}{c|}{ Sig. } \\
\hline 1 & (Constant) & .224 & .407 & & .550 & .587 \\
\cline { 2 - 8 } & CSRscore & .047 & .016 & .443 & 3.022 & .005 \\
\cline { 2 - 8 } & Firmsize & -.037 & .023 & -.258 & -1.607 & .118 \\
\cline { 2 - 8 } & Leverage & -.139 & .109 & -.204 & -1.269 & .214 \\
\hline
\end{tabular}

EJBE Vol. 5 No. 2/2015 
CSR and Financial Performance of Manufacturing Companies

\begin{tabular}{|l|l|r|r|r|r|r|}
\hline \multicolumn{7}{|c|}{ ANOVA $^{\mathbf{b}}$} \\
\hline \multirow{2}{*}{ Model } & $\begin{array}{c}\text { Sum of } \\
\text { Squares }\end{array}$ & df & Mean Square & F & Sig. \\
\hline 1 & Regression & .421 & 3 & .140 & 5.541 & $.004^{\mathrm{a}}$ \\
\cline { 2 - 8 } & Residual & .760 & 30 & .025 & & \\
\cline { 2 - 8 } & Total & 1.181 & 33 & & & \\
\hline $\begin{array}{l}\text { a. Dependent Variable: } \\
\text { ROA }\end{array}$ & & & & & \\
\hline
\end{tabular}

\section{B) Dependent Variable: ROE}

\begin{tabular}{|l|c|r|r|l|}
\hline \multicolumn{7}{|c|}{ Model Summary } \\
\hline Model & R & R Square & $\begin{array}{c}\text { Adjusted R } \\
\text { Square }\end{array}$ & $\begin{array}{c}\text { Std. Error of the } \\
\text { Estimate }\end{array}$ \\
\hline 1 & $.637^{\mathrm{a}}$ & .405 & .346 & .24770 \\
\hline \multicolumn{2}{|l|}{ a. Predictors: (Constant), Leverage, CSRscore, Firmsize } \\
\hline
\end{tabular}

\begin{tabular}{|c|c|c|c|c|c|c|}
\hline \multicolumn{7}{|c|}{ ANOVA $^{b}$} \\
\hline \multicolumn{2}{|c|}{ Model } & $\begin{array}{l}\text { Sum of } \\
\text { Squares }\end{array}$ & $\mathrm{df}$ & Mean Square & $\mathrm{F}$ & Sig. \\
\hline \multirow[t]{3}{*}{1} & Regression & 1.254 & 3 & .418 & 6.811 & $.001^{\mathrm{a}}$ \\
\hline & Residual & 1.841 & 30 & .061 & & \\
\hline & Total & 3.094 & 33 & & & \\
\hline \multicolumn{5}{|c|}{$\begin{array}{l}\text { a. Predictors: (Constant), Leverage, CSRscore, } \\
\text { Firmsize }\end{array}$} & & \\
\hline \multicolumn{3}{|c|}{ b. Dependent Variable: ROE } & & & & \\
\hline
\end{tabular}

\begin{tabular}{|c|c|c|c|c|c|c|}
\hline \multicolumn{7}{|c|}{ Coefficients $^{\mathrm{a}}$} \\
\hline \multirow{2}{*}{\multicolumn{2}{|c|}{ Model }} & \multicolumn{2}{|c|}{$\begin{array}{l}\text { Unstandardized } \\
\text { Coefficients }\end{array}$} & \multirow{2}{*}{$\begin{array}{c}\text { Standardized } \\
\text { Coefficients } \\
\text { Beta }\end{array}$} & \multirow[b]{2}{*}{$\mathrm{t}$} & \multirow[b]{2}{*}{ Sig. } \\
\hline & & B & $\begin{array}{l}\text { Std. } \\
\text { Error }\end{array}$ & & & \\
\hline \multirow[t]{4}{*}{1} & (Constant) & .227 & .634 & & .358 & .723 \\
\hline & CSRscore & .096 & .024 & .551 & 3.908 & .000 \\
\hline & Firmsize & -.071 & .036 & -.304 & -1.965 & .059 \\
\hline & Leverage & $-1.797 \mathrm{E}-5$ & .170 & .000 & .000 & 1.000 \\
\hline
\end{tabular}

EJBE Vol. 5 No. 2/2015 
CSR and Financial Performance of Manufacturing Companies

\begin{tabular}{|c|c|c|c|c|c|c|}
\hline \multicolumn{7}{|c|}{ Coefficients $^{\mathrm{a}}$} \\
\hline \multirow{2}{*}{\multicolumn{2}{|c|}{ Model }} & \multicolumn{2}{|c|}{$\begin{array}{c}\text { Unstandardized } \\
\text { Coefficients }\end{array}$} & \multirow{2}{*}{$\begin{array}{c}\text { Standardized } \\
\text { Coefficients } \\
\text { Beta }\end{array}$} & \multirow[b]{2}{*}{$\mathrm{t}$} & \multirow[b]{2}{*}{ Sig. } \\
\hline & & B & $\begin{array}{l}\text { Std. } \\
\text { Error }\end{array}$ & & & \\
\hline \multirow[t]{4}{*}{1} & (Constant) & .227 & .634 & & .358 & .723 \\
\hline & CSRscore & .096 & .024 & .551 & 3.908 & .000 \\
\hline & Firmsize & -.071 & .036 & -.304 & -1.965 & .059 \\
\hline & Leverage & $-1.797 \mathrm{E}-5$ & .170 & .000 & .000 & 1.000 \\
\hline & endent & ble: & & & & \\
\hline
\end{tabular}

\section{C) Dependent Variable: ROS}

\begin{tabular}{|l|r|r|r|r|}
\hline \multicolumn{5}{|c|}{ Model Summary } \\
\hline Model & \multicolumn{1}{|c|}{$\mathrm{R}$} & R Square & $\begin{array}{c}\text { Adjusted R } \\
\text { Square }\end{array}$ & $\begin{array}{c}\text { Std. Error of the } \\
\text { Estimate }\end{array}$ \\
\hline 1 & $.604^{\mathrm{a}}$ & .365 & .301 & .18345 \\
\hline a. Predictors: (Constant), Leverage, CSRscore, Firmsize \\
\hline
\end{tabular}

EJBE Vol. 5 No. 2/2015 
CSR and Financial Performance of Manufacturing Companies

\begin{tabular}{|c|c|c|c|c|c|c|c|}
\hline \multicolumn{8}{|c|}{ ANOVA $^{b}$} \\
\hline \multicolumn{2}{|c|}{ Model } & \multicolumn{2}{|c|}{$\begin{array}{l}\text { Sum of } \\
\text { Squares }\end{array}$} & $\mathrm{df}$ & Mean Square & \multirow{2}{*}{$\frac{F}{5.736}$} & \multirow{2}{*}{$\begin{array}{l}\text { Sig. } \\
.003^{\mathrm{a}}\end{array}$} \\
\hline \multirow[t]{3}{*}{1} & Regression & & .579 & 3 & .193 & & \\
\hline & Residual & & 1.010 & 30 & .034 & & \\
\hline & Total & & 1.589 & 33 & & & \\
\hline \multicolumn{6}{|c|}{$\begin{array}{l}\text { a. Predictors: (Constant), Leverage, CSRscore, } \\
\text { Firmsize }\end{array}$} & & \\
\hline \multicolumn{4}{|c|}{ b. Dependent Variable: ROS } & & & & \\
\hline \multicolumn{8}{|c|}{ Coefficients $^{\mathrm{a}}$} \\
\hline & & \multicolumn{3}{|c|}{$\begin{array}{l}\text { Unstandardized } \\
\text { Coefficients }\end{array}$} & $\begin{array}{l}\text { Standardized } \\
\text { Coefficients }\end{array}$ & & \\
\hline \multicolumn{2}{|c|}{ Model } & B & Std. Error & & Beta & $\mathrm{t}$ & Sig. \\
\hline \multirow[t]{4}{*}{1} & (Constant) & -.111 & .46 & 59 & & -.237 & .815 \\
\hline & CSRscore & .069 & .01 & 18 & .554 & 3.807 & .001 \\
\hline & Firmsize & -.039 & .02 & 27 & -.232 & -1.452 & .157 \\
\hline & Leverage & .017 & .12 & 26 & .022 & .139 & .891 \\
\hline & $\begin{array}{l}\text { ependent } \\
\text { able: ROS }\end{array}$ & & & & & & \\
\hline
\end{tabular}

